\title{
Fatigue on Oil Refinery Workers and Related Factors
}

\author{
Iwan Muhamad Ramdan * (D), Krishna Purnawan Candra² (D), Ulfah Rana Mahdiyyah ${ }^{1}$ \\ ${ }^{1}$ Department of Public Health, Mulawarman University, Samarinda, Indonesia; ${ }^{2}$ Department Agricultural Product Technology, \\ Faculty of Agriculture, Mulawarman University, Samarinda, Indonesia
}

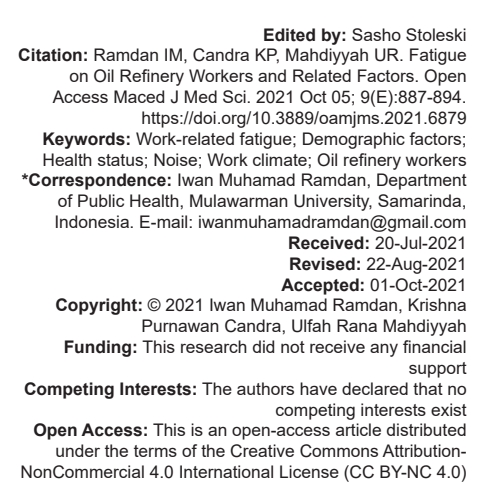

\section{Introduction}

Oil and gas is an industry with a high level of occupational safety and health risks. Some potential hazards that can be found in this sector include transportation activities, being struck by an object, falling from heights, exposure to chemical materials, and working in confined space, slips, trips, explosions, and fires [1]. At the stage of oil refining, workers have different risks of health and safety problems depending on the location of work. Workers in oil fields, drilling rigs, and other oil production workplaces are exposed to various chemical hazards, fire and explosion, physical strain, exposure to high noise, exposure to oil on the skin, and increased work stress due to work often isolated locations [2]. Other research reported that oil refining industry workers are exposed to various health hazards, e.g. physical (noise), chemical $\left(\mathrm{O}_{2}, \mathrm{CO}\right.$, $\mathrm{NH}_{3}, \mathrm{C}_{2} \mathrm{H}_{4}$, and $\mathrm{H}_{2} \mathrm{~S}$ ), mechanical/ergonomic (obsolete machines and equipment), and biological (organic dust/carbon black) [3].

Work accidents in the oil and gas sector in the last decade are also severe. The risk of death due to work accidents of oil and gas workers is 8.5 times higher than that of other sector workers. Most of the causes of accidents experienced are related to work fatigue due to longer work hours (more than $20 \mathrm{~h}$ per day) [4], research in this sector is needed to detect critical risk factors early to prevent accidents [5].

Work fatigue plays a significant role in all industries regarding performance, work safety, and work productivity [6]. The impact of work fatigue on industrial workers has caused considerable losses, estimated work fatigue has spent more than $\$ 18$ billion per year due to loss or decline in work productivity. Work fatigue in the oil and gas industry has a devastating effect. It can trigger disasters, such as the BP Texas City Incident in 2005, which resulted in the death of 15 workers, 180 injuries, and losses of at least $\$ 1.5$ billion and the Piper oil rig disaster. Alpha resulted in the death of 167 workers. It is estimated that $80 \%$ of industrial work accidents are caused by a human error related to work fatigue [7]. Other studies prove work fatigue is significantly associated with work overload, work situation awareness, and work performance [8], [9]. Other adverse effects of work fatigue for workers include impaired cognitive 
functioning and health problems such as depression and cardiovascular diseases [10].

The causes of work fatigue in each industry are different. Three factors cause work fatigues, namely physical (forceful exertion, awkward posture, static load, and repetition movement), mental (irregular work hours, job demands, job stress, co-worker relationships, and autonomy deviation), and environmental load (temperature, noise, light level, vibration, and humidity) [11], [12]. Other studies have concluded that the leading causes of work fatigue are sleep quality [1], [3], changes in circadian rhythm [13], work shifts [14], lack of sleep, work stress and poor medical history [15], work-family conflicts [16], and labor emotional disharmony [17]. Based on various research publications, research on work fatigue in oil and gas workers (especially oil refinery workers) still requires a more specific and complete investigation.

This study aimed to analyze the prevalence of work fatigue of oil refinery workers and the related factors, i.e., demographic characteristics, work environment, and workers' health status.

\section{Design and Methods}

A cross-sectional study was conducted between September until November 2019 on all plants in the oil refinery plant of an oil company in Indonesia. Respondents in this study were sampled from the oil refinery workers population of 511 . Slovin's formula was applied to collect respondents by random sampling of a total of 224 respondents, i.e., 65 workers from hydroskimming plant, 122 workers from the hydrocracking plant, 59 workers distilling and wax plant, 101 workers from utilities, 106 workers from oil movement, and 58 workers from the laboratory.

Demographic characteristics (age, education, marital status, and working period) were measured using a questionnaire. Work fatigue is measured by the Japanese Industrial Fatigue Research Committee [18]. This questionnaire consists of 30 question items. In general, this questionnaire consisted of 3 parts, the first ten questions revealed "weakening of activities", the second ten questions revealed "weakening motivation", and the third ten questions reveal "physical weakening". The questionnaire used five Likert scales with the answer options consisting of: (1) Never, (2) sometimes, (3) being felt regularly, (4) often experienced, and (5) always experienced. Total scores are obtained by summing all scores per item, then categorized into four work fatigue categories: (1) Scores 30-52 is "low"; (2) scores 53-75 is "medium"; (3) scores 76-98 is "high"; and (4) scores 99-120 is "very high".

Noise exposure is measured using a sound level meter (Monotaro, Japan), work climate is measured using a heat stress monitor (Questemp-34 heat stress meter, USA). The determination of the threshold limit value (TLV) of noise and work climate is based on Indonesia's Minister of Manpower Regulation number 05 of 2018, where the TLV of noise for $8 \mathrm{~h}$ of work is $85 \mathrm{~dB}$, and the TLV of working climate with the Wet Bulb Globe Temperature parameter is $28^{\circ} \mathrm{C}$. The health status of workers in this study was obtained through a medical examination using three indicators (blood pressure, body temperature, and respiratory rate). Workers' blood pressure classification is based on JNC 7 classification of blood pressure for adults [19], as follows:

\begin{tabular}{lll}
\hline Blood pressure classification & Systole $(\mathrm{mm} \mathrm{Hg})$ & Diastole $(\mathrm{mm} \mathrm{Hg})$ \\
\hline Normal & $<120$ & $<80$ \\
Prehypertension & $120-139$ & $80-89$ \\
Stage 1 & $140-159$ & $90-99$ \\
Stage 2 & $\geq 160$ & $\geq 100$ \\
\hline
\end{tabular}

The worker's respiratory rate classification used in this study was adopted from London's Royal College of Physicians [20]. Based on this classification, the normal reference range for people age 18 to 65 is 16-20 breaths per minute, bradypnea is $<60$ breaths per minute, and tachypnea $>100$ breaths per minute. In addition, Cramer's V test was applied to see the correlation between work fatigue and independent variables (demographic characteristics, exposure to noise and work climate, and the health status of workers). Data analysis was done using the Statistical Package for the Social Sciences (SPSS ver. 21, Chicago, IL, USA).

\section{Results}

The distribution of age, sex, education background, marital status, body temperature, respiratory rate, systole, and diastole of oil refinery workers is shown in Table 1.

The age of workers is varying in each oil refinery plant section. The age of the workers was mainly 37-42 years old, which was distributed at hydrocracking, hydro skimming, and the utility plant, as well as at the oil movement for 30.19, 28.57, 36.36, and $29.79 \%$, respectively. At the distilling and wax plant and laboratory, workers' age was mainly 31-36 years old, distributed at $30.77 \%$ and $38.46 \%$, respectively. Most workers had more than 10 years of experience in all plant sections (57.69-88.68\%). The workers' educational background and marital status in all refinery plant sections were graduate (29.55-53.85\%) and married (71.4-92.3\%), respectively.

The oil refinery workers' body temperature mainly was in hypothermia and normal categories. The normal body temperature was primarily found in hydrocracking plant $(52.8 \%)$, in distilling and wax plant $(57.7 \%)$, and laboratory $(50.0 \%)$. In comparison, the 
Table 1a: Demography and health characteristics of oil refinery workers and the environmental condition at the oil refinery plants (a) Demographic characteristics and health condition

\begin{tabular}{|c|c|c|c|c|c|c|c|c|c|c|c|c|}
\hline \multirow[t]{2}{*}{ Variables } & \multicolumn{2}{|c|}{$\mathrm{HC}(\mathrm{n}=53)$} & \multicolumn{2}{|c|}{$\mathrm{HS}(\mathrm{n}=28)$} & \multicolumn{2}{|c|}{ UTL $(n=44)$} & \multicolumn{2}{|c|}{$\operatorname{DWP}(n=26)$} & \multicolumn{2}{|c|}{$\mathrm{OM}(\mathrm{n}=47)$} & \multicolumn{2}{|c|}{$\operatorname{Lab}(n=26)$} \\
\hline & freq & $\%$ & freq & $\%$ & freq & $\%$ & freq & $\%$ & freq & $\%$ & freq & $\%$ \\
\hline \multicolumn{13}{|l|}{ Age (years) } \\
\hline $25-30$ & 11 & 20.75 & 5 & 17.86 & 9 & 20.45 & 5 & 19.23 & 12 & 25.53 & 3 & 11.54 \\
\hline $31-36$ & 13 & 24.53 & 6 & 21.43 & 10 & 22.73 & 8 & 30.77 & 9 & 19.15 & 10 & 38.46 \\
\hline $37-42$ & 16 & 30.19 & 8 & 28.57 & 16 & 36.36 & 7 & 26.92 & 14 & 29.79 & 6 & 23.08 \\
\hline $43-48$ & 8 & 15.09 & 6 & 21.43 & 5 & 11.36 & 4 & 15,38 & 9 & 19.15 & 2 & 7.69 \\
\hline $49-54$ & 5 & 9.43 & 3 & 10.71 & 4 & 9.09 & 2 & 7.69 & 3 & 6.38 & 5 & 19.23 \\
\hline \multicolumn{13}{|l|}{ Working period (years) } \\
\hline$<5$ & 2 & 3.77 & 2 & 7.14 & 3 & 6.82 & 0 & 0.00 & 2 & 4.26 & 1 & 3.85 \\
\hline $5-10$ & 4 & 7.55 & 8 & 28.57 & 13 & 29.55 & 8 & 30.77 & 13 & 27.66 & 10 & 38.46 \\
\hline$>10$ & 47 & 88.68 & 19 & 67.86 & 28 & 63.64 & 18 & 69.23 & 32 & 68.09 & 15 & 57.69 \\
\hline \multicolumn{13}{|l|}{ Education background } \\
\hline Graduated from $12^{\text {th }}$ & 8 & 15.09 & 4 & 14.29 & 8 & 18.18 & 4 & 15.38 & 7 & 14.89 & 3 & 11.54 \\
\hline \multicolumn{13}{|l|}{ Class } \\
\hline Diploma III & 10 & 18.87 & 7 & 25.00 & 9 & 20.45 & 5 & 19.23 & 9 & 19.15 & 5 & 19.23 \\
\hline Diploma IV & 6 & 11.32 & 2 & 7.14 & 6 & 13.64 & 1 & 3.85 & 6 & 12.77 & 1 & 3.85 \\
\hline Graduate & 18 & 33.96 & 10 & 35.71 & 13 & 29.55 & 13 & 50.00 & 15 & 31.91 & 14 & 53.85 \\
\hline Postgraduate & 11 & 20.75 & 5 & 17.86 & 3 & 6.82 & 3 & 11.54 & 10 & 21.28 & 3 & 11.54 \\
\hline \multicolumn{13}{|l|}{ Marital status } \\
\hline Unmarried & 5 & 9.4 & 5 & 17.9 & 2 & 4.5 & 2 & 7.7 & 4 & 8.5 & 4 & 14.3 \\
\hline Married & 45 & 84.9 & 22 & 78.6 & 39 & 88.6 & 24 & 92.3 & 41 & 87.2 & 20 & 71.4 \\
\hline Ever been married & 3 & 5.7 & 1 & 3.6 & 3 & 6.8 & 0 & 0 & 2 & 4.3 & 2 & 7.1 \\
\hline \multicolumn{13}{|l|}{ Body temperature } \\
\hline Hypothermia & 22 & 41.5 & 24 & 85.7 & 29 & 65.9 & 11 & 42.3 & 27 & 57.4 & 10 & 35.7 \\
\hline Normal & 28 & 52.8 & 4 & 14.3 & 14 & 31.8 & 15 & 57.7 & 20 & 42.6 & 14 & 50.0 \\
\hline Hyperthermia & 3 & 5.7 & 0 & 0 & 1 & 2.3 & 0 & 0 & 0 & 0 & 2 & 7.1 \\
\hline \multicolumn{13}{|l|}{ Respiratory rate } \\
\hline Bradypnea & 8 & 15.1 & 0 & 0 & 2 & 4.5 & 1 & 3.8 & 0 & 0 & 1 & 3.6 \\
\hline Normal & 41 & 77.4 & 25 & 89.3 & 33 & 75.0 & 22 & 84.6 & 29 & 61.7 & 16 & 57.1 \\
\hline Tachypnea & 4 & 7.5 & 3 & 10.7 & 9 & 20.5 & 3 & 11.5 & 18 & 38.3 & 9 & 32.1 \\
\hline \multicolumn{13}{|l|}{ Systole } \\
\hline Normal & 13 & 24.5 & 6 & 21.4 & 15 & 34.1 & 7 & 26.9 & 11 & 23.4 & 7 & 25.0 \\
\hline Prehypertension & 30 & 56.6 & 13 & 46.4 & 19 & 43.2 & 13 & 50.0 & 26 & 55.3 & 13 & 46.4 \\
\hline Stage 1 & 10 & 18.9 & 9 & 32.1 & 10 & 22.7 & 6 & 23.1 & 10 & 21.3 & 6 & 21.4 \\
\hline Stage 2 & 0 & 0.0 & 0 & 0.0 & 0 & 0.0 & 0 & 0.0 & 0 & 0.0 & 0 & 0.0 \\
\hline \multicolumn{13}{|l|}{ Diastole } \\
\hline Normal & 13 & 24.5 & 6 & 21.4 & 15 & 34.1 & 7 & 26.9 & 11 & 23.4 & 7 & 25.0 \\
\hline Prehypertension & 30 & 56.6 & 13 & 46.4 & 19 & 43.2 & 13 & 50.0 & 26 & 55.3 & 13 & 46.4 \\
\hline Stage 1 & 10 & 18.9 & 9 & 32.1 & 10 & 22.7 & 6 & 23.1 & 10 & 21.3 & 6 & 21.4 \\
\hline Stage 2 & 0 & 0.0 & 0 & 0.0 & 0 & 0.0 & 0 & 0.0 & 0 & 0.0 & 0 & 0.0 \\
\hline
\end{tabular}

hypothermic body temperature was primarily found at the hydro-skimming plant $(85.7 \%)$, at the utility plant (65.9\%), and the oil movement plant (57.4\%).

The oil refinery workers' respiratory rate mainly was normal in the range of $57.1-89.3 \%$. The highest respiratory rate is found in the hydro-skimming plant, and the lowest is found in the laboratory. The systole and diastole data show that the oil workers' blood pressure was categorized in prehypertension with the systole and diastole range of $43.2-56.6 \%$.

Table 1b: Demography and health characteristics of oil refinery workers and the environmental condition at the oil refinery plants (b) The environmental condition of the oil refinery plant

\begin{tabular}{lllllll}
\hline Variables & HC & HS & UTL & DWP & OM & Lab \\
\hline Noise exposure & $>$ TLV & $>$ TLV & $>$ TLV & $<$ TLV & $<$ TLV & $<$ TLV \\
Heat exposure & $>$ TLV & $>$ TLV & $>$ TLV & $>$ TLV & $>$ TLV & $<$ TLV \\
\hline
\end{tabular}
$\begin{array}{lllll}\text { Heat exposure }>\text { TLV }>\text { TLV }>\text { TLV }>\text { TLV }>\text { TLV }<\text { TLV } & <\text { Theq (frequency) and percentage within each oil refinery plant column are calculated based on }\end{array}$ the number of respondents in each refinery plant. HC: Hydrocracking, HS: Hydro skimming, UTL: Utilities, DWP: Distilling and wax plant, OM: Oil movement, Lab: Laboratory, TLV: Threshold limit value, for noise and heat stress exposure are $85 \mathrm{~dB}$ and $28^{\circ} \mathrm{C}$ (wet bulb temperature), respectively.

Three oil refinery plant sections, namely hydrocracking, hydro-skimming, and utility plant, have noise above TLV. In comparison, five from six oil refinery plant sections have heat stress above TLV, i.e., hydrocracking hydro-skimming, utilities, distilling and wax, and oil movement plant.

Table 2 shows the distribution of work-related fatigue (WRF) levels experienced by the oil refinery workers. Work at an oil refinery is at high risk. Most oil refinery workers generally experienced WRF at a medium level, i.e., $49.2 \%$, followed by high and very high levels of $27.9 \%$ and $14.3 \%$, respectively. The distribution of WRF prevalence among the oil refinery workers is varying depending on the plant section types. The WRF level is distributed in all categories (low to very high). All respondents who work at the hydrocracking plant section (100\%) experienced WRF at a high level. The respondents who work at utilities, distilling and wax, oil movement plant section, and laboratory experienced the WRF mostly at a medium level (61.3-96.1\%).

Table 2: Distribution of WRF s prevalence among the oil refinery workers at different plant areas

\begin{tabular}{|c|c|c|c|c|c|c|c|c|c|c|}
\hline \multirow[t]{2}{*}{ Oil refinery plant } & \multirow[t]{2}{*}{$\mathrm{n}$} & \multirow[t]{2}{*}{$\mathrm{n}$} & \multicolumn{2}{|c|}{ Low } & \multicolumn{2}{|c|}{ Medium } & \multicolumn{2}{|c|}{ High } & \multicolumn{2}{|c|}{ Very high } \\
\hline & & & freq & $\%$ & freq & $\%$ & freq & $\%$ & freq & $\%$ \\
\hline (1) & (2) & (3) & (4) & (5) & (6) & (7) & (8) & (9) & (10) & (11) \\
\hline Hydrocracking & 122 & 53 & 0 & 0.00 & 0 & 0.00 & 53 & 100.0 & 0 & 0.0 \\
\hline Hydro-skimming & 65 & 28 & 4 & 14.2 & 2 & 7.1 & 7 & 10.25 & 15 & 53.5 \\
\hline Utilities & 101 & 44 & 13 & 29.5 & 27 & 61.3 & 4 & 9.09 & 0 & 0.0 \\
\hline Distilling and Wax & 59 & 26 & 1 & 0.38 & 25 & 96.1 & 0 & 0.0 & 0 & 0.0 \\
\hline Oil Movement & 106 & 47 & 1 & 2.1 & 43 & 91.4 & 3 & 6.38 & 0 & 0.0 \\
\hline Laboratory & 58 & 26 & 2 & 7.6 & 23 & 88.4 & 1 & 3.8 & 0 & 0.0 \\
\hline Total & 511 & 244 & 21 & 8.6 & 120 & 49.2 & 68 & 27.9 & 15 & 14.3 \\
\hline
\end{tabular}
respondents are a man. WRF: Work-related fatigue.

The correlation of demographic characteristics of the oil refinery workers and WRF is presented in Table 3. Among the six oil refinery plant sections, only the hydrocracking plant section shows a significant correlation between WRF and some demographic characteristics of the oil refinery workers. Working period $(p=0.037, r=0.795)$, respiratory rate $(p=0.026$, $r=0.852$ ), and blood pressure (diastolic, $p=0.047$, $r=0.274)$ are the three demographic characteristics 
Table 3: Intrinsic characteristics of oil refinery workers ( $n=244$ ) and the association with symptoms and WRF s prevalence in every work area

\begin{tabular}{|c|c|c|c|c|c|c|c|c|}
\hline \multirow{3}{*}{$\begin{array}{l}\text { Demographic } \\
\text { characteristics of } \\
\text { workers at each oil } \\
\text { refinery plant section }\end{array}$} & \multirow{2}{*}{\multicolumn{2}{|c|}{ WRFs }} & \multicolumn{6}{|c|}{ Weakening type } \\
\hline & & & \multicolumn{2}{|c|}{ Activities } & \multicolumn{2}{|c|}{ Motivation } & \multicolumn{2}{|c|}{ Physical } \\
\hline & $r$ & $\mathrm{p}$ & $r$ & $p$ & $\mathrm{r}$ & $\mathrm{p}$ & $r$ & $\mathrm{p}$ \\
\hline \multicolumn{9}{|l|}{ Hydrocracking } \\
\hline Age & 0.112 & 0.424 & 0.190 & 0.173 & 0.072 & 0.610 & 0.048 & 0.731 \\
\hline Working period & 0.795 & 0.037 & 0.626 & 0.069 & 0.876 & 0.022 & 0.860 & 0.025 \\
\hline Body temperature & -0.124 & 0.377 & 0.089 & 0.526 & -0.121 & 0.388 & -0.127 & 0.364 \\
\hline Respiratory rate & 0.852 & 0.026 & -0.294 & 0.033 & 0.648 & 0.000 & 0.808 & 0.000 \\
\hline Systole & -0.240 & 0.053 & -0.294 & 0.033 & 0.648 & 0.000 & 0.808 & 0.000 \\
\hline Diastole & -0.274 & 0.047 & -0.294 & 0.033 & 0.648 & 0.000 & 0.808 & 0.000 \\
\hline \multicolumn{9}{|l|}{ Hydro-skimming } \\
\hline Age & -0.053 & 0.788 & 0.057 & 0.772 & 0.015 & 0.940 & -0.237 & 0.224 \\
\hline Working period & -0.304 & 0.116 & -0.263 & 0.175 & -0.314 & 0.103 & -0.252 & 0.196 \\
\hline Body temperature & -0.299 & 0.240 & -0.037 & 0.853 & -0.282 & 0.146 & -0.321 & 0.095 \\
\hline Respiratory rate & 0.252 & 0.196 & 0.307 & 0.111 & 0.203 & 0.301 & 0.176 & 0.371 \\
\hline Systole & 0.274 & 0.159 & 0.217 & 0.267 & 0.247 & 0.205 & 0.290 & 0.134 \\
\hline Diastole & 0.254 & 0.191 & 0.168 & 0.393 & 0.220 & 0.260 & 0.318 & 0.099 \\
\hline \multicolumn{9}{|l|}{ Utilities } \\
\hline Age & -0.238 & 0.120 & -0.255 & 0.142 & -0.220 & 0.152 & -0.128 & 0.407 \\
\hline Working period & -0.132 & 0.399 & -0.229 & 0.135 & -0.143 & 0.354 & 0.037 & 0.812 \\
\hline Body temperature & 0.038 & 0.805 & 0.019 & 0.903 & 0.028 & 0.855 & 0.041 & 0.792 \\
\hline Respirato & -0.077 & 0.621 & -0.238 & 0.120 & 0.088 & 0.571 & 0.000 & 1.000 \\
\hline Systole & -0.173 & 0.260 & -0.191 & 0.213 & 0.034 & 0.828 & -0.199 & 0.195 \\
\hline Diastole & -0.069 & 0.656 & -0.043 & 0.738 & -0.070 & 0.650 & -0.053 & 0.731 \\
\hline \multicolumn{9}{|l|}{ Distilling and wax } \\
\hline Age & 0.136 & 0.506 & -0.007 & 0.974 & 0.110 & 0.594 & 0.163 & 0.425 \\
\hline Working period & -0.164 & 0.432 & 0.039 & 0.848 & -0.166 & 0.417 & -0.195 & 0.340 \\
\hline Body $t$ & -0.251 & 0.215 & -0.085 & 0.680 & -0.356 & 0.460 & -0.046 & 0.824 \\
\hline Respiratory rate & -0.022 & 0.917 & -0.065 & 0.752 & 0.132 & 0.522 & -0.107 & 0.603 \\
\hline Systole & 0.054 & 0.793 & 0.234 & 0.250 & 0.030 & 0.855 & -0.166 & 0.418 \\
\hline Diastole & 0.140 & 0.496 & 0.245 & 0.229 & 0.072 & 0.726 & -0.052 & 0.800 \\
\hline \multicolumn{9}{|l|}{ Oil movement } \\
\hline Age & 0.032 & 0.832 & 0.199 & 0.427 & -0.142 & 0.341 & 0.032 & 0.832 \\
\hline Workir & -0003 & 0.984 & -0.006 & 0.966 & 0.027 & 0.855 & -0.018 & 0.906 \\
\hline Body tem & 0.054 & 0.721 & 0.100 & 0.504 & -0.042 & 0.780 & 0.028 & 0.852 \\
\hline Respiratory rate & -0.193 & 0.194 & -0.223 & 0.132 & -0.229 & 0.122 & 0.007 & 0.965 \\
\hline Systole & 0.006 & 0.966 & 0.076 & 0.611 & -0.185 & 0.214 & 0.055 & 0.714 \\
\hline Diastole & 0.090 & 0,55 & 25 & 0.483 & -0.033 & 0.825 & 0.091 & 0.545 \\
\hline \multicolumn{9}{|l|}{ Laboratory } \\
\hline Age & -0.094 & 0.649 & 0.004 & 0.985 & -0.091 & 0.660 & -0.121 & 0.555 \\
\hline ) & -0.120 & 0.560 & -0.355 & 0.075 & 0.250 & 0.218 & -0.143 & 0.485 \\
\hline Body temperature & 0.135 & 0.512 & 0.224 & 0.272 & -0.103 & 0.617 & 0.167 & 0.416 \\
\hline Respiratory rate & 0.230 & 0.258 & 0.229 & 0.260 & 0.224 & 0.270 & 0.008 & 0.967 \\
\hline Systole & 0.001 & 0.997 & -0.073 & 0.723 & 0.104 & 0.612 & -0.030 & 0.883 \\
\hline Diastole & 0.019 & 0.927 & -0.001 & 0.995 & 0.092 & 0.654 & -0.060 & 0.769 \\
\hline
\end{tabular}

that should have more attention in elucidating the WRF issues among oil refinery workers.

At the hydrocracking plant, the demographic characteristics (working period, respiratory rate, and blood pressure), correlated significantly to WRF, also significantly relate to motivation and physical weakening by having the correlation factor $p$-value between 0.000 and 0.025 (Table 3).

The noise $(p=0.000, r=0.248)$ and heat stress exposure $(p=0.030, r=0.656)$ was correlated significantly to the WFR among the oil refinery workers (Table 4). Therefore, fixing these issues is needed to overcome the WRF among the oil refinery workers caused by the noise and heat exposure at oil refinery plants, which shows a higher value than TLV (Table 1b). Furthermore, the noise and heat stress exposure was also correlated significantly with

Table 4: Correlation of work environment with WRF of oil refinery workers

\begin{tabular}{|c|c|c|c|c|c|c|c|c|}
\hline \multirow[t]{3}{*}{ Variables } & \multirow{2}{*}{\multicolumn{2}{|c|}{ WRFs }} & \multicolumn{6}{|c|}{ Weakening type } \\
\hline & & & \multicolumn{2}{|c|}{ Activities } & \multicolumn{2}{|c|}{ Motivation } & \multicolumn{2}{|c|}{ Physical } \\
\hline & $\mathrm{r}$ & $\mathrm{p}$ & $\mathrm{r}$ & $p$ & $\bar{r}$ & $p$ & $r$ & $\mathrm{p}$ \\
\hline Noise exposure & 0.248 & 0.000 & 0.478 & 0.000 & 0.873 & 0.000 & 0.901 & 0.000 \\
\hline Heat stress exposure & 0.656 & 0.030 & 0.466 & 0.049 & 0.672 & 0.028 & 0.306 & 0.059 \\
\hline
\end{tabular}

Note: Data were analyzed by Cramer's $V(\phi C)$, WRF: Work-related fatigue. the weakening of activities, motivation, and physic of the oil refinery workers by having the correlation power $p$-value between 0.000 and 0.049 , except the heat exposure with physical weakening $(p=0.059)$ (Table 4).

Figure 1 shows the symptoms profile of the activities, motivation, and physical weakening among the oil refinery workers at each plant type. The figure explores the symptoms profile of each weakening, i.e., activities, motivation, and physic. At the hydrocracking plant, oil refinery workers who experienced weakening symptoms in motivation and physic were detected as "always" and "regularly" at a level of about $30-70 \%$. In contrast, the activities weakening was not an issue.

At the five other oil refinery plant sections, the demographic and health characteristics were insignificantly related to weakening activities, motivation, and physic (Table 3). However, Figure 1 shows that all weakening is becoming a severe issue. The workers who experienced WRF showing all the three weakening symptoms at "always" and "regularly" levels of $20-60 \%$ and $20-80 \%$, respectively.

Figure 1 also shows issues with the activities and physical weakening at the utility plant section. The number of workers who experienced WRF shows the two weakening symptoms at a "regularly" level of about $20-30 \%$ for activities weakening and $30-50 \%$ for physical weakening.

At distilling and wax, and oil movement plant sections, as well as laboratory, the issue of WRF was only with the physical weakening. Nevertheless, the number of workers experienced thirsty at an "always" level of about $55-70 \%$ (Figure 1).

\section{Discussion}

\section{WRF prevalence}

We found that all workers experienced job burnout with various categories and occurs in motivation weakening and physics dimensions. This condition requires immediate treatment so that the adverse effects of work fatigue experienced such as work accidents [5] and decreased work productivity [21] do not occur.

\section{Factors affected WRF prevalence}

\section{Demographic factors and WRF}

The demographic factors of workers significantly related to work fatigue in this study are only the working period (length of work). In contrast, the age of the workers, level of education, and marital status were 


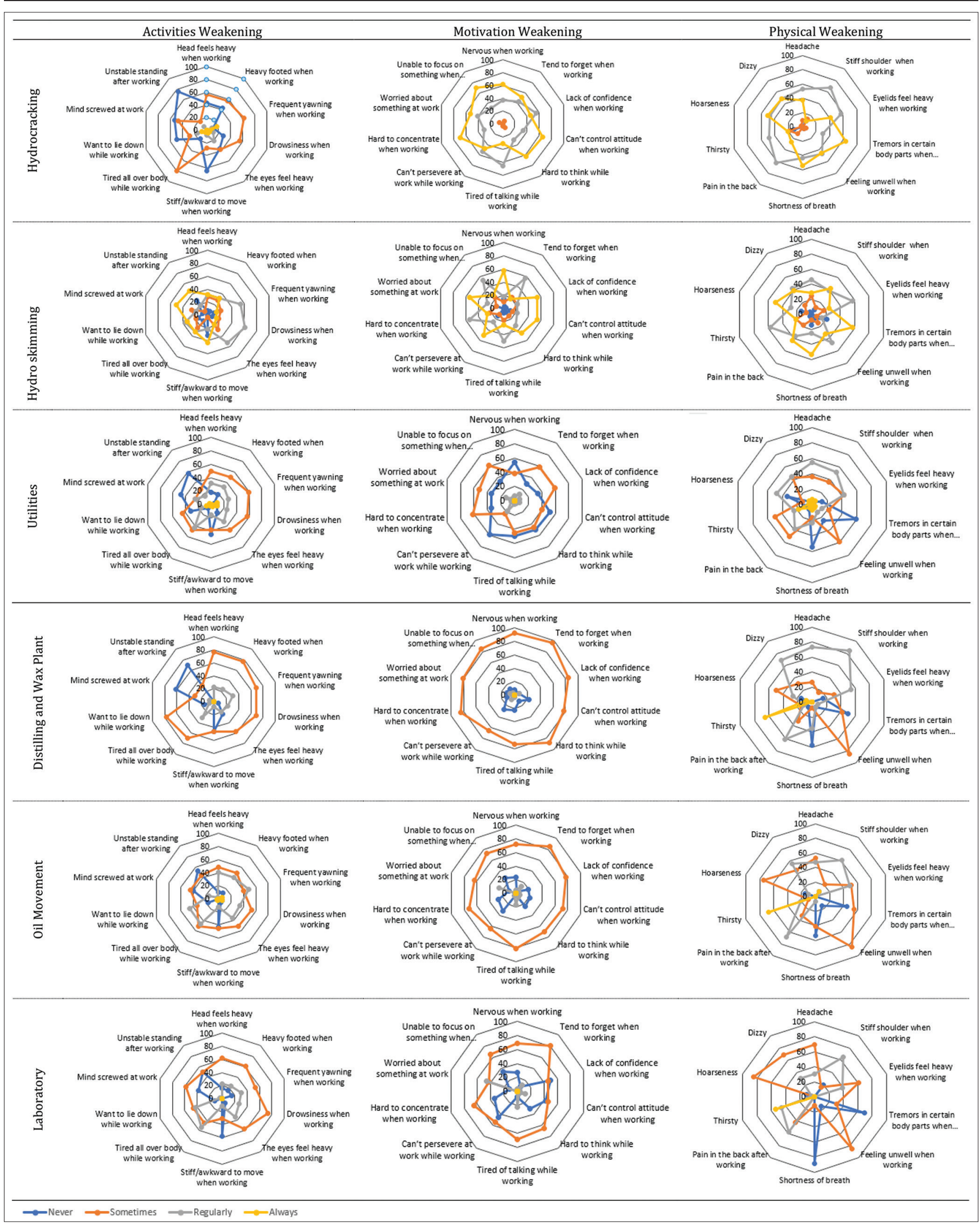

Figure 1: Distribution of weakening symptoms of oil refinery workers at different plant areas having work-related fatigues prevalence. This figure is related to Table 3

not found to be related to work fatigue. The relationship of work period related to work fatigue is understandable because the increase in work-life illustrates an increase in an age where there is a decrease in body capacity (physical and cognitive) in accepting workload [22].
As workers' age increases, there will be a decrease in physiological abilities of various body organs, decreased metabolic function, and reduced adaptability to physical and psychological stress [23], [24]. On the other hand, the addition of a working period will improve 
job skills. Workers with high job skills will be a more efficient use of energy in completing the work demands that may slow the experience of fatigue.

The results of this study complement the results of previous studies, which reported that marital status, education level, years of service, and mental health status of workers are significantly related to chronic fatigue syndrome [25]. The opposite report showed no correlation between demographic characteristics (age, body mass index, marital status, education level, and shift work) and work-related factors in oil and gas industry workers in Iran [26] and Malaysia [27]. Work fatigue for female workers at Holland with a high education level had $44 \%$ higher odds of reporting high WRF when compared with women with a low or intermediate level of education [9]. Perceived health status, age, and gender are related to work fatigue, but education level is not correlated [28]. Unmarried status was more associated with fatigue than was married status and being overworked [29].

\section{Health status and WRF}

In this study, the health status of workers was assessed based on three vital sign indicators (blood pressure, body temperature, and respiratory rate). The results of blood pressure measurements found that most workers $(50.9 \%)$ were in prehypertension status, the results of body temperature measurements of most workers $(53.6 \%)$ were within normal limits $\left(36^{\circ} \mathrm{C}-37^{\circ} \mathrm{C}\right)$, and respiratory rate measurement results from the majority $(74.1 \%)$ were normal. Statistical test results showed that only respiratory rate was significantly related to work fatigue $(p=0.018)$.

A vital sign is the simplest, cheapest, and most widely performed important information to describe a person's health status. Although this method has long been used and now has become an area of active research, early detection of changes in vital signs can prevent worse health conditions [30]. This study proves the relationship between the health status of workers with work fatigue. These results make sense because blood pressure measures the strength of the heart in pumping blood throughout the body through arteries. At the same time, breathing is breathing oxygen from the air and releasing carbon dioxide and water vapor. Therefore, changes in blood pressure and respiratory rate from normal limits will affect the blood supply to cells/tissues, which will involve work fatigue.

These results are in line with studies of work fatigue in other occupations that conclude a relationship between the health status of workers with WRF, among others, perceived physical health and perceived mental health, and psychological distress was associated with work fatigue among employees in Taiwan [31], medical personnel in Taiwan with poor and very poor selfreported health were more likely to report WRF [32].

\section{Noise and heat stress exposure and WRF}

The results found that most of the workers $(55.8 \%)$ were exposed to noise above TLV (85 dB), i.e., workers in the HCC, HSC, and UTL sections. Furthermore, almost all workers (88.4\%) were exposed to a work climate above TLV (WBG Parameters $28^{\circ} \mathrm{C}$ ), i.e., workers in the HSC, HCC, dis-waxed, UT, and OM sections. Only workers in the laboratory are not exposed to work temperatures above the TLV.

Statistical tests prove a significant relationship between noise exposure and work fatigue. These results are in line with the opinion of Kjellberg et al. [33], which stated that noise might have fatiguing effects as noise may contribute to a general over-stimulation. In addition, monotonous noise has been found to have sleep-provoking effects and noise may make the task more difficult and tiring to perform, for example, by masking important acoustic information. In addition, Münzel et al. [34] concluded that noise exposure could cause sleep disturbances which will ultimately cause work fatigue. Studies on the architect concluded that changes in sleep rest patterns due to noise induce frequent arousals, increase the duration of frequent awakenings, increase autonomic arousals, and increase heart rate.

Our finding can complement the research results on other types of work, such as Fredriksson et al. [35], which concluded that health personnel occupational noise and work stress correlated significantly with work fatigue. In addition, Saremi et al. [29] proved that high noise exposure significantly increased the level of work fatigue. Noise exposure is an essential factor causing work fatigue in chemical plant workers in France. Hebrani et al. [36] concluded that noise exposure was significantly related to work fatigue in Indonesia's oil and gas industry workers.

This study implies that various control efforts must be made to reduce noise exposure in the workplace to reduce work fatigue in oil refinery workers. Following the hierarchy of hazard control in the workplace from $\mathrm{NIOSH}$ [37], noise control at work can be carried out using elimination, substitution, engineering control, administrative control, and personal protective equipment.

Statistical tests prove that exposure to high working temperatures is significantly related to work fatigue. These results follow a new model introduced by Ismaila et al. [38] who explain the interaction model of the effects of hyperthermia on various body systems that lead to fatigue. In the cardiovascular system, hyperthermia decreases cardiac output, which causes the supply of blood flow to the muscles to fall and affects blood flow to the brain, thereby disrupting the balance of brain heat. Hyperthermia in the central nervous system could cause neurobiological changes. They affect motor activity and psychological conditions and lead to decreased motivation, mood, pain 
tolerance, and expectation of task demand. Finally, in the respiratory system, heat pressure will be increased ventilation, lowered $\mathrm{PaCO}^{2}$, increased $\mathrm{pH}$, and causing breathlessness.

This study can complement previous studies on various types of work, which concluded that exposure to high environmental temperatures is significantly related to work fatigue. Chen et al. [39] reported that steel plant workers in Taiwan exposed to a hot environment are inclined to subjective fatigue. Their fatigue symptoms increase with the heat exposure levels. MakowiecDąbrowska et al. [40] concluded that heat exposure was significantly related to work fatigue in professional drivers in Poland.

This result implies that work fatigue for oil refinery workers can be reduced through efforts to control heat exposure. According to the recommendations of $\mathrm{NIOSH}$ [41], controlling heat exposure at workplace can be done through control of heat stress (engineering control and safe work practices), train workers before hot outdoor work begins, acclimatization, hydration, and rest breaks.

\section{Conclusion}

All oil refinery workers experienced work fatigue, and it is categorized as low, medium, high, and very high for $8.6,49.2,27.9$, and $14.3 \%$, respectively. Hydrocracking is the only plant section having the issue with WRF. The WRF prevalences at the section are related significantly to the working period, respiratory rate, and blood pressure. In addition, the working period is related significantly to motivation and physical weakening. At the same time, the respiratory rate and blood pressure correlated significantly with all weakening types, i.e., activities, motivation, and physical. Besides, noise exposure and heat stress are also related significantly to WRF prevalences. The noise exposure is significantly associated with all weakening types, while the heat stress is associated only with activities and motivation weakening. Therefore, the companies should improve the health status of workers and reduce the workload for aging workers. Preventing noise exposure and heat stress is also recommended to minimize WRF prevalence.

\section{References}

1. Witter RZ, Tenney L, Clark S, Newman LS. Occupational exposures in the oil and gas extraction industry: State of the science and research recommendations. Am J Ind Med. 2015;344(6188):1173-8. https://doi.org/10.1002/ajim.22316

\section{PMid:24634090}

2. Safari S, Akbari J, Kazemi M, Mououdi MA, Mahaki B. Personnel's health surveillance at work: Effect of age, body mass index, and shift work on mental workload and work ability index. J Environ Public Health. 2013;2013:289498. https://doi. org/10.1155/2013/289498

\section{PMid:23956756}

3. Eyayo F. Evaluation of occupational health hazards among oil industry workers: A case study of refinery workers. J Environ Sci Toxicol Food Technol. 2014;8(12):22-53. https://doi. org/10.9790/2402-081212253

4. Johnson D. Fatigue is the Enemy of Many Oil and Gas Workers Industrial Safety and Hygene News (ISHN); 2018. Available from: https://www.ishn.com/articles/108217-fatigue-is-the-enemy-ofmany-oil-and-gas-workers. [Last accessed on 2021 Aug 04].

5. Chan M. Fatigue: The most critical accident risk in oil and gas construction. Constr Manag Econ. 2011;29(4):341-53.

6. Williamson A, Lombardi DA, Folkard S, Stutts J, Courtney TK Connor JL. The link between fatigue and safety. Accid Anal Prev. 2011;43(2):498-515. https://doi.org/10.1016/j.aap.2009.11.011 PMid:21130213

7. Shortz AE, Mehta RK, Peres SC, Benden ME, Zheng Q. Development of the fatigue risk assessment and management in high-risk environments (FRAME) survey: A participatory approach. Int J Environ Res Public Health. 2019;16(4):522. https://doi.org/10.3390/ijerph16040522 PMid:30781731

8. Khodabakhsh MR. The role of fatigue and work overload in predicting work situation awareness among workers. Int J Occup Hyg. 2015;7(1):38-44. Available from: http://www.ijoh.tums.ac.ir/ index.php/ijoh/article/view/128. [Last accessed on 2021 Aug 04].

9. Verdonk P, Hooftman WE, van Veldhoven MJ, Boelens LR, Koppes LL. Work-related fatigue: The specific case of highly educated women in the Netherlands. Int Arch Occup Environ Health. 2010;83(3):309-21. https://doi.org/10.1007/ s00420-009-0481-y PMid:19888593

10. de Vries JD, van Hooff ML, Geurts SA, Kompier MA Exercise to reduce work-related fatigue among employees: A randomized controlled trial. Scand J Work Environ Health. 2017;43(4):337-49. https://doi.org/10.5271/sjweh.3634 PMid:28323305

11. Horrey WJ, Noy YI, Folkard S, Popkin SM, Howarth HD, Courtney TK. Research needs and opportunities for reducing the adverse safety consequences of fatigue. Accid Anal Prev. 2011;43(2):591-4. https://doi.org/10.1016/j.aap.2010.01.014 PMid:21130219

12. Azwar A, Susilowati IH, Dinar A, Indriyani K, Wirawan M. Impact of work-related and non-work-related factors on fatigue in production/shift workers. KnE Life Sci. 2018;4(5):213. https:// doi.org/10.18502/kls.v4i5.2554

13. Lerman SE, Eskin E, Flower DJ, George EC, Gerson B, Hartenbaum $\mathrm{N}$, et al. Fatigue risk management in the workplace. J Occup Environ Med. 2012;54(2):231-58. https:// doi.org/10.1097/jom.0b013e318247a3b0 PMid:22269988

14. Ummul S, Kameswara R. Shift work and fatigue. J Environ Sci. 2012;1(3):17-21.

15 Masson VA, Monteiro MI, Vedovato TG. Workers of CEASA: Factors associated with fatigue and work ability. Rev Bras Enferm. 2015;68(3):401-7. https://doi. org/10.1590/0034-71167.2015680312i

16. Dohrmann SB, Herttua K, Leppin A. Fatigue in ferry shipping employees: The role of work-family conflict and supervisor support. BMC Public Health. 2019;19(1):1693. https://doi. 
org/10.1186/s12889-019-7954-z

PMid:31847825

17. Lee JJ, Moon HJ, Lee KJ, Kim JJ. Fatigue and related factors among hotel workers: The effects of emotional labor and non-standard working hours. Ann Occup Environ Med. 2014;26(1):51. https://doi.org/10.1186/s40557-014-0051-y PMid:25648050

18. Saito K. Measurement of fatigue in industries. Ind Health. 1999;37(2):134-42.

PMid:10319563

19. Schwartz GL, Sheps SG. A Review of the Sixth Report of the Joint National Committee on Prevention, Detection, Evaluation, and Treatment of High Blood Pressure. Vol. 14. Washington DC: Current Opinion in Cardiology; 1999. Available from: https://www.nhlbi.nih.gov/files/docs/guidelines/ jnc7full.pdf. [Last accessed on 2021 Aug 04]. https://doi. org/10.1097/00001573-199903000-00014

20. Royal College of Physicians. National Early Warning Score (NEWS) 2, Standarising the Assessment of AcuteIllness Severity in the NHS. London, UK: Royal College of Physicians; 2017. Available from: https://www.rcplondon. ac.uk/projects/outputs/national-early-warning-score-news-2. [Last accessed on 2021 Aug 04]. https://doi.org/10.7717/ peerj.6947/table-1

21. O'Neill C, Panuwatwanich K. The impact of fatigue on labour productivity: Case study of dam construction project in Queensland. In: Proceedings of the $4^{\text {th }}$ International Conference on Engineering, Project, and Production Management (EPPM 2013); 2013. p. 993-1005. https://doi.org/10.32738/ ceppm.201310.0095

22. Abd-Elfattah HM, Abdelazeim FH, Elshennawy S. Physical and cognitive consequences of fatigue: A review. J Adv Res. 2015;6(3):351-8. https://doi.org/10.1016/j.jare.2015.01.011 PMid:26257932

23. Hsu HC. Age differences in work stress, exhaustion, well-being, and related factors from an ecological perspective. Int J Environ Res Public Health. 2019;16(1):50. https://doi.org/10.3390/ ijerph16010050

PMid:30585250

24. Åkerstedt T, Discacciati A, Miley-Åkerstedt A, Westerlund $\mathrm{H}$. Aging and the change in fatigue and sleep-a longitudinal study across 8 years in three age groups. Front Psychol. 2018;9:234. https://doi.org/10.3389/fpsyg.2018.00234 PMid:29568279

25. Stevelink SA, Fear NT, Hotopf M, Chalder T. Factors associated with work status in chronic fatigue syndrome. Occup Med (Lond). 2019;69(6):453-8. https://doi.org/10.1093/occmed/kqz108 PMid:31375832

26. Bazazan A, Rasoulzadeh Y, Dianat I, Safaiyan A. Demographic factors and their relation to fatigue and mental disorders in 12-hour petrochemical shift workers. Health Promot Perspect. 2014;4(2):165-72. https://doi.org/10.3233/wor-192865 PMid:25648196

27. Ismail S, Mohd Zaki N, Abu Husain M. Managing health risk among shift workers in the oil and gas industry in Malaysia. Int J Civ Eng Technol. 2019;10(1):1439-49. Available from: http://www.iaeme.com/ijciet/index.asp1439; http://www.iaeme. com/ijciet/issues.asp?jtype=ijciet and vtype $=10$ and itype $=01$; http://www.iaeme.com/ijciet/index.asp1440; http://www.iaeme. com/ijciet/issues.asp?jtype=ijciet and vtype=10 and itype=01. [Last accessed on 2021 Aug 04]. https://doi.org/10.31227/osf. io/pnqjz

28. Stynen D, Jansen NW, Kant J. The impact of work-related and personal resources on older workers' fatigue, work enjoyment and retirement intentions over time. Ergonomics. 2017;60(12):1692-707. https://doi.org/10.1080/00140139.201 7.1334094

PMid:28532293

29. Saremi M, Rohmer O, Bonnefond A. Combined effects of noise and shift work on fatigue as a function of age. Int J Occup Saf Ergon. 2008;14(4):387-94

PMid:19080043

30. Brekke IJ, Puntervoll LH, Pedersen PB, Kellett J, Brabrand M. The value of vital sign trends in predicting and monitoring clinical deterioration: A systematic review. PLoS One. 2019;14(1):e0210875. https://doi.org/10.1371/journal. pone. 0210875

PMid:30645637

31. Tang FC, Li RH, Huang SL. The association between job-related psychosocial factors and prolonged fatigue among industrial employees in Taiwan. PLoS One. 2016;11(3):1-12. https://doi. org/10.1371/journal.pone.0150429

PMid:26930064

32. Ho JC, Lee MB, Chen RY, Chen CJ, Chang WP, Yeh CY, et al Work-related fatigue among medical personnel in Taiwan. J Formos Med Assoc. 2013;112(10):608-15. PMid:23809098

33. Kjellberg A, Muhr P, Sköldström B. Fatigue after work in noise-an epidemiological survey study and three quasi-experimental field studies. Noise Health. 1998;1(1):47-55.

PMid:12689367

34. Münzel T, Sørensen M, Schmidt F, Schmidt E, Steven S, KröllerSchön S, et al. The adverse effects of environmental noise exposure on oxidative stress and cardiovascular risk. Antioxid Redox Signal. 2018;28(9):873-908. https://doi.org/10.1089/ ars.2017.7118

PMid:29350061

35. Fredriksson S, Hammar O, Torén K, Tenenbaum A, Waye KP. The effect of occupational noise exposure on tinnitus and sound-induced auditory fatigue among obstetrics personnel: A cross-sectional study. BMJ Open. 2015;5(3):e005793. https:// doi.org/10.1136/bmjopen-2014-005793 PMid:25818267

36. Hebrani O, Madonna S, Nursetyowati P. The effect of noise on work fatigue in an oil and gas industry. Indones $\mathrm{J}$ Urban Environ Technol. 2018;1(2):109. https://doi.org/10.25105/ urbanenvirotech.v1i2.2426

37. NIOSH. Hierarchy of Controls. Centers for Disease Control and Prevention; 2007.

38. Ismaila SO, Akanbi OG, Oderinu SO. Design of ergonomically compliant desks and chairs for primary pupils in Ibadan, Nigeria. J Eng Sci Technol. 2015;10(1):35-46.

39. Chen ML, Chen CJ, Yeh WY, Huang JW, Mao IF. Heat stress evaluation and worker fatigue in a steel plant. AlHA J (Fairfax, Va). 2003;64(3):352-9. https://doi. org/10.1080/15428110308984827 PMid:12809541

40. Makowiec-Dąbrowska T, Gadzicka E, Siedlecka J, SzyjkowskaA Viebig P, Kozak P, et al. Climate conditions and work-related fatigue among professional drivers. Int J Biometeorol. 2019;63(2):121-8. https://doi.org/10.1007/s00484-018-1643-y PMid:30411249

41. Jacklitsch B, Williams W, Musolin K, Coca A, Kim JH, Turner N. NIOSH Criteria for a Recommended Standard: Occupational Exposure to Heat and Hot Environments. United States: US Department of Health and Human Services; 2016. p. 2016-106. https://doi.org/10.26616/nioshpub2016106 